Halaman : $021-031$

\title{
ANALISIS PELAKSANAAN PRAKTIKUM PADA MATA PELAJARAN BIOLOGI DI KELAS X SMA NEGERI 16 MEDAN
}

\author{
Fitri Siburian $^{1)^{*}}$, Masdiana Sinambela ${ }^{2)}$, Septie $^{3)}$ \\ ${ }^{\mathbf{1 , 2}}$ Program Studi Pendidikan Biologi, FMIPA, Universitas Negeri Medan, Medan JI. Willem Iskandar Psr. V Medan \\ Estate, Medan, Indonesia, 20221 \\ ${ }^{3}$ SMA Negeri 16 Medan, Jalan Kapten Rahmad Buddin, 20256 \\ *E-mail : fitri20.siburian@gmail.com
}

\begin{abstract}
ABSTRAK
Penelitian ini bertujuan untuk mengetahui pelaksanaan praktikum Biologi di kelas X SMA N 16 Medan, Populasi dalam penelitian ini adalah seluruh siswa kelas X di SMA N 16 Medan yang berjumlah 240 orang siswa. Sampel yang digunakan yaitu kelas X Mia 1 dan X Mia 4 yang berjumlah 80 orang. Manfaat hasil penelitian ini sebagai pertimbangan dalam perbaikan pelaksanaan praktikum biologi dimasa akan datang dan memberikan informasi mengenai pelaksanaan praktikum biologi di SMA N 16 Medan. Penelitian yang dilakukan termasuk penelitian deskriptif kuantitatif dengan perhitungan persentase. Hasil analisis menunjukkan bahwa peralatan yang ada di laboratorium cukup baik dengan persentase 58\%, alokasi waktu saat praktikum cukup baik dengan persentase 58,8\%, penggunaan waktu yang cukup saat praktikum baik dengan persentase $62,2 \%$, pendalaman materi biologi melalui kegiatan praktikum baik dengan persentase 66,9\%, memahami prosedur kerja pada saat praktikum baik dengan persentase $71,9 \%$, membuat laporan praktikum baik dengan persentase $73,43 \%$, guru menyampaikan tujuan praktikum sangat baik dengan persentase $85,62 \%$.
\end{abstract}

Kata kunci : Pelaksanaan Praktikum, Praktikum Biologi, Masalah Praktikum

\section{ABSTRACT}

This study aims to determine the implementation of Biology practicum in class X SMA N 16 Medan, Population in this study is all students of class X in SMA N 16 Medan, amounting to 240 students. The sample used is class X Mia 1 and X Mia 4 which amounted to 80 people. The benefits of this study as a consideration in improving the implementation of biological practice in the future and provide information about the implementation of biological practice in SMA N 16 Medan. The research conducted included quantitative descriptive research with percentage calculation. The results showed that the equipment in the laboratory is quite good with the percentage of $58 \%$, the allocation of time when the lab is quite good with the percentage of $58.8 \%$, the use of sufficient time when practicum either with $62.2 \%$ percentage, deepening of biological material through good lab work With percentage of $66,9 \%$, understanding work procedure at the time of good practice with percentage $71,9 \%$, make good practice report with percentage $73,43 \%$, teacher deliver very good practice purpose with percentage $85,62 \%$.

Keywords : Implementation of Practicum, Biological Practicum, Practicum Problem

\section{PENDAHULUAN}

Pembelajaran biologi merupakan wahana untuk meningkatkan pengetahuan, keterampilan sikap dan nilai serta tanggung jawab kepada lingkungan. Biologi berkaitan dengan cara mencari tahu tentang alam secara sistematis, sehingga pembelajaran biologi bukan hanya penguasaan kumpulan-kumpulan pengetahuan yang berupa fakta-fakta, konsep atau prinsip-prinsip saja, tetapi juga merupakan suatu proses penemuan (Hamidah, 2014).

Salah satu kegiatan yang menerapkan metode ilmiah dalam pembelajaran biologi adalah dengan kegiatan praktikum. Kegiatan praktikum termasuk ke dalam metode pembelajaran eksperimen yang memberikan pengalaman langsung kepada siswa berkaitan dengan teori pembelajaran. Praktikum merupakan bagian penting dalam proses pembelajaran. Setiap sekolah wajib memiliki laboratorium dan melaksanakan kegiatan praktikum. Secara formal praktikum sudah menjadi komponen dalam pembelajaran IPA khususnya biologi, namun tampaknya pelaksanaan praktikum di sekolah masih belum optimal untuk mencapai tujuan praktikum yang mendukung teori pembelajaran (Atnur, 2014). 
Kegiatan praktikum dapat membantu siswa untuk mencapai hasil belajar yang diinginkan serta penerapannya dikehidupan sehari-hari sesuai dengan pendalaman materi yang telah didapatkannya. Praktikum merupakan salah satu dari faktor-faktor yang mempengaruhi hasil belajar siswa yang sangat berperan penting dalam menunjang keberhasilan proses belajar mengajar. Praktikum memberi peluang kepada siswa untuk memperdalam pemahamannya terhadap materi ajar yang akan diperoleh melalui kegiatan belajar mengajar di kelas dan akan memberikan landasan baru bagi siswa untuk lebih kreatif dalam melakukan praktikum.

Laboratorium biologi memiliki peran yang penting dalam menunjang kegiatan praktikum, diperlukan sarana dan prasarana laboratorium yang baik agar kegiatan praktikum dapat berjalan dengan lancar. Penelitian menyatakan bahwa terdapat hubungan positif antara keadaan laboratorium dengan hasil belajar siswa, artinya semakin baik keadaan laboratorium maka hasil belajar siswa semakin bagus. Selain itu, pemanfaatan laboratorium atau intensitas kegiatan praktikum di laboratorium biologi dapat meningkatkan hasil belajar siswa (Oktavia, 2012).

Pelaksanakan praktikum di laboratorium berdasarkan penelitian yang telah dilakukan oleh Muliadong (2015) menunjukkan bahwa pelaksanaan praktikum biologi di SMA N 1 diperoleh nilai rata-rata persentase secara keseluruhan sebesar 85,22\% dengan kriteria baik sedangkan pelaksanaan praktikum di SMA $\mathrm{N} 2$ diperoleh nilai rata-rata persentase secara keseluruhan sebesar 74,99\% dengan kriteria cukup.

Dalora (2014) dalam penelitiannya menyatakan bahwa pelaksanaan praktikum biologi di SMA Negeri se-Kota Jambi sudah baik, siswa telah mempersiapkan alat dan bahan praktikum sebelum pelaksanaan praktikum, sehingga pada saat praktikum siswa sudah siap dengan materi yang akan dipraktikumkan, laporan dan evaluasi praktikum sudah sangat baik, siswa membuat hasil laporan sesuai dengan petunjuk yang diberikan oleh guru.

Penelitian yang telah dilaksanakan Hamidah (2014) menunjukkan bahwa kegiatan praktikum biologi di Laboratorium SMA Negeri se-kota Jambi sudah terlaksana dengan baik sebesar $65,38 \%$, namun masih ada kendala dan kesulitan yang dialami oleh guru dalam pelaksanaan praktikum. Berbagai kendala yang masih dihadapi oleh guru dalam pelaksanaan kegiatan praktikum biologi adalah keberadaan laboratorium biologi itu sendiri karena $40 \%$ laboratorium biologi di SMA Negeri se-kota Jambi yang tidak digunakan sebagai tempat praktikum biologi, melainkan dijadikan ruang kelas untuk belajar.

Pada penelitian Salwa (2014) permasalahan yang dihadapi dalam pelaksanaan praktikum Biologi semester gasal kelas XI di SMA Negeri se Kabupaten Karo tahun ajaran 2010/2011 yang paling utama adalah kurangnya waktu yang tersedia untuk pelaksanaan praktikum (41\%) yang terdiri dari alokasi waktu yang kurang baik dengan persentase $46 \%$ dan praktikum di luar jam pelajaran Biologi yang tidak baik $35 \%$. Lalu disusul dengan keadaan laboratorium (59\%) yang kurang baik dengan perincian peralatan laboratorium 63\%, perlengkapan laboratorium 56\%, tata tertib dilaboratorium $45 \%$ serta kebersihan laboratorium $62 \%$. Kemudian pemanfaatan laboratorium di SMA Negeri se Kabupaten Karo tahun ajaran 2010/2011 masih tergolong tidak baik atau sangat rendah.

Berdasarkan hasil observasi saya tgl 23 januari 2017 disekolah SMA N 16 Medan, pelaksanaan praktikum biologi di sekolah tidak memiliki jadwal khusus, guru menentukan sendiri kapan praktikum akan dilaksanakan, tidak adanya laboran yang membantu guru untuk mempersiapkan alat dan bahan yang akan digunakan pada saat praktikum. Dari kegiatan praktikum di harapkan siswa di SMA N 16 Medan mampu mencapai nilai KKM yang di tetapkan guru mata pelajaran biologi untuk kelas $X$ yaitu 70 .

Tujuan penelitian ini adalah untuk mengetahui apakah praktikum biologi dilaksanakan dengan baik di kelas X SMA N 16 Medan, mengetahui faktor-faktor yang menghambat pelaksanaan praktikum biologi dan mengetahui kendala-kendala yang dialami guru dalam pelaksanaan praktikum biologi di kelas X SMA N 16 Medan.

\section{METODE PENELITIAN}

Penelitian ini telah dilaksanakan di SMA Negeri 16 Medan beralamat di jalan Kapten Rahmad Budin, Kecamatan Medan Marelan pada bulan Desember sampai Juni tahun 2017.

Jenis penelitian ini adalah deskriptif kuantitatif. Populasi dalam penelitian ini adalah seluruh kelas $X$ di sekolah SMA N 16 Medan yang berjumlah 6 kelas dengan 240 siswa Tahun Pembelajaran 2016/2017. Sampel penelitian inii diambil secara Random Sampling yaitu X Mia 1 dan X Mia 4 yang berjumlah 80 siswa.

Untuk memperoleh data yang dibutuhkan, maka instrumen yang digunakan dalam penelitian ini, 
Halaman : $021-031$

yaitu angket, wawancara dan observasi di laboratorium.

Angket yang digunakan adalah angket tertutup yang terdiri dari 30 pernyataan. Masing-masing pernyataan disediakan pilihan yang menjadi alternatif jawaban. Setiap item dari angket berisi 4 pilihan yaitu : Tiap option A memiliki bobot 4, Tiap option B memiliki bobot 3, Tiap option $C$ memiliki bobot 2, Tiap option $D$ memiliki bobot 1 . Tujuan wawancara dengan guru bidang studi biologi adalah untuk mengetahui jadwal

$P=\frac{\mathrm{f}}{\mathrm{n}} \times 100 \%$

Keterangan :

$P=$ Persentase option yang dijawab responden

$f=$ Jumlah frekuensi

$\mathrm{n}=$ Jumlah responden

Keterangan hasil presentasi :

$$
\begin{aligned}
81-100 \% & =\text { Sangat baik } \\
61-80 \% & =\text { Baik } \\
41-60 \% & =\text { Cukup Baik } \\
21-40 \% & =\text { Kurang Baik } \\
0-20 \% & =\text { Kurang Sekali }
\end{aligned}
$$

(Sudijono, 2010) kegiatan praktikum yang mendukung dalam penyusunan angket. Observasi laboratorium biologi meliputi : pengamatan terhadap kondisi dan ketersediaan perlengkapan dan peralatan di laboratorium yang mendukung pelaksanaan praktikum Biologi di kelas X SMA N 16 Medan Tahun Pembelajaran 2016/2017. Teknik analisis data angket digunakan dalam penelitian ini adalah teknik analisis deskriptif dengan perhitungan persentase yang diperoleh dengan memakai rumus.

Analisis pelaksanaan praktikum tiap indikator diperoleh dengan cara sebagai berikut :

$$
\text { Persentase skor }=\frac{\text { Skor peroleh siswa untuk indikator }}{\text { Skor maksimal }} \times 100 \%
$$

(Wahyuni, 2013)

\section{HASIL PENELITIAN}

Dari data hasil penelitian dan wawancara dengan guru biologi menunjukkan bahwa siswa kelas X SMA N 16 Medan memiliki beberapa materi yang dipraktikumkan, namun tidak semua materi yang seharusnya dipraktikumkan tersebut terlaksana dengan baik, hanya ada 5 materi yang terlaksana dan ada 5 materi yang tidak terlaksana. Hasil penelitian menunjukkan bahwa sembilan indikator yang

\begin{tabular}{|c|c|c|c|c|}
\hline Indikator & No. Item/ Deskriptor & Jumlah skor $(\Sigma)$ & Persentase & Kriteria \\
\hline Keadaan & 1. Peralatan & 184 & 57,5 & Cukup baik \\
\hline \multirow[t]{3}{*}{ Laboratorium } & 2. Tata tertib & 223 & 69,68 & Baik \\
\hline & 3. Kebersihan ruangan & 243 & 75,93 & Baik \\
\hline & $\begin{array}{l}\text { 4. Menggunakan alat keselamatan saat } \\
\text { praktikum }\end{array}$ & 247 & 77,18 & Baik \\
\hline Waktu & 1. Alokasi Waktu & 188 & 58,75 & Cukup baik \\
\hline $\begin{array}{l}\text { pelaksanaan } \\
\text { praktikum }\end{array}$ & $\begin{array}{l}\text { 2. Melakukan praktikum pemanfaatan } \\
\text { alam }\end{array}$ & 86 & 26,87 & Kurang baik \\
\hline $\begin{array}{l}\text { Buku penuntun } \\
\text { praktikum }\end{array}$ & $\begin{array}{l}\text { 1. Kesesuaian pelaksanaan praktikum } \\
\text { dengan penuntun praktikum. }\end{array}$ & 222 & 69,37 & Baik \\
\hline
\end{tabular}
ditanyakan pada penelitian ini dapat dijadikan sebagai gambaran tentang pelaksanaan praktikum yang dapat disesuaikan dengan data hasil wawancara kepada guru bidang studi biologi.

Tabel 2. Persentase Jawaban Angket Siswa Berdasarkan Indikator 


\begin{tabular}{|c|c|c|c|c|}
\hline $\begin{array}{l}\text { Ketersediaan } \\
\text { Waktu }\end{array}$ & $\begin{array}{l}\text { 1. Kesesuaian praktikum dengan jadwal } \\
\text { biologi yang telah ditentukan. } \\
\text { 2. Penggunaan waktu yang cukup dalam } \\
\text { praktikum } \\
\text { 3. Ada tidaknya waktu tambahan dalam } \\
\text { melakukan praktikum. }\end{array}$ & 199 & 62,18 & Cukup baik \\
\hline Materi & $\begin{array}{l}\text { 1. Kesesuaian prosedur kerja dengan } \\
\text { materi biologi } \\
\text { 2. Pendalaman materi biologi melalui } \\
\text { kegiatan praktikum }\end{array}$ & 244 & 76,25 & Baik \\
\hline $\begin{array}{l}\text { Pelaksanaan } \\
\text { praktikum }\end{array}$ & $\begin{array}{l}\text { 1. Hasil pengamatan sesuai dengan } \\
\text { prosedur kerja } \\
\text { 2. Memahami prosedur kerja pada } \\
\text { kegiatan praktikum } \\
\text { 3. Guru mengadakan tes tertulis sebelum } \\
\text { praktikum } \\
\text { 4. Pernah atau tidak melaksanakan ujian } \\
\text { tes } \\
\text { 5. Kesempatan untuk mengamati } \\
\text { praktikum } \\
\text { 6. Memakai jas laboratorium pada saat } \\
\text { praktikum biologi }\end{array}$ & $\begin{array}{l}180 \\
240 \\
232\end{array}$ & 75 & $\begin{array}{l}\text { Baik } \\
\text { Cukup baik } \\
\text { Baik }\end{array}$ \\
\hline $\begin{array}{l}\text { Lembar Kerja } \\
\text { Siswa }\end{array}$ & $\begin{array}{l}\text { 1. Diberikan atau tidak lembar kerja } \\
\text { siswa pada saat melakukan praktikum } \\
\text { 2. Lembar kerja siswa tersebut di } \\
\text { pergunakan atau tidak pada saat } \\
\text { melakukan praktikum }\end{array}$ & 205 & 54,68 & Cukup baik \\
\hline $\begin{array}{l}\text { Pembuatan } \\
\text { Laporan }\end{array}$ & $\begin{array}{l}\text { 1. Membuat laporan praktikum biologi } \\
\text { 2. Kendala membuat laporan praktikum } \\
\text { biologi } \\
\text { 3. Mencatat hasil pengamatan praktikum } \\
\text { 4. Dikumpulkan atau tidak laporan } \\
\text { praktikum biologi } \\
\text { 5. Guru mengoreksi laporan praktikum } \\
\text { 6. Guru mengembalikan laporan } \\
\text { praktikum yang telah di koreksi } \\
\text { 7. Menarik kesimpulan dari hasil } \\
\text { praktikum }\end{array}$ & $\begin{array}{l}212 \\
244 \\
240 \\
247\end{array}$ & $\begin{array}{l}66,25 \\
76,25\end{array}$ & $\begin{array}{l}\text { Baik } \\
\text { Baik } \\
\text { Baik } \\
\text { Baik }\end{array}$ \\
\hline $\begin{array}{l}\text { Persiapan } \\
\text { praktikum }\end{array}$ & $\begin{array}{l}\text { 1. Pengelompokan siswa } \\
\text { 2. Peran guru } \\
\text { 3. Guru menyampaikan tujuan praktikum }\end{array}$ & $\begin{array}{l}216 \\
254 \\
274\end{array}$ & $\begin{array}{c}67,5 \\
79,37 \\
85,62\end{array}$ & $\begin{array}{l}\text { Baik } \\
\text { Baik } \\
\text { Sangat baik }\end{array}$ \\
\hline
\end{tabular}

Selain menggunakan angket, peneliti juga menggunakan instrument pengumpulan data berupa wawancara dengan guru bidang studi biologi. Hasil wawancara yang penulis lakukan adalah sebagai berikut.

\section{Tentang Keadaan Laboratorium}

- Peralatan di laboratorium SMA N 16 Medan : Peralatan di laboratorium cukup lengkap, namun ada beberapa alat yang tidak tersedia di laboratorium seperti neraca, potometer, termometer suhu tanah, kuadrat, dan sop watch.

- Kebersihan ruangan laboratorium : Setiap selesai melaksanakan praktikum, ruangan praktikum selalu dibersihkan. 
- Laboratorium biologi terpisah atau digabung dengan laboratorium fisika dan kimia : Laboratorium biologi digabung dengan laboratorium fisika dan kimia.

\section{Alokasi Waktu}

- Waktu pelaksanaan praktikum dilakukan sejalan dengan jam pelajaran tetapi tidak ada waktu khusus.

- Berapa kali praktikum dilaksanakan : Praktikum dilaksanakan \pm 3 kali dalam satu semester.

- Cukup atau tidak waktu praktikum yang telah tersedia : Waktu yang dilakukan cukup dan selalu selesai sesuai dengan jadwal yang telah ditentukan.

- Pernah atau tidak melakukan praktikum pemanfaatan alam (praktikum di luar ruangan) : Pernah, namun hanya sekali pada saat praktikum keanekaragaman hayati.

\section{Materi}

- Prosedur kerja sesuai atau tidak dengan materi pelajaran yang ingin dipraktikumkan : Prosedur kerja sesuai dengan materi pelajaran biologi yang akan dipraktikumkan.

- Materi pelajaran yang seharusnya dipraktikumkan dilaksanakan semua atau tidak : Tidak semua yang seharusnya dipraktikumkan terlaksana, hanya materi tentang ruang lingkup biologi, keanekaragaman hayati, virus, jamur dan kingdom plantae yang diterlaksana sedangkan materi tentang Archaeobacteria, kingdom protista, kingdom animalia, ekosistem dan pencemaran lingkungan tidak terlaksana.

\section{Pelaksanaan dan Hasil Belajar}

- Bagaimana keaktifan siswa melaksanakan praktikum :

Sebagian siswa aktif dalam melakukan praktikum dan sebagian lagi kurang aktif dalam melakukan praktikum

- Bagaimana nilai biologi siswa setelah dilaksanakan praktikum : Nilai biologi siswa meningkat setelah dilaksanakan kegiatan praktikum

- Berapa nilai KKM mata pelajaran biologi kelas X : Nilai KKM mata pelajaran biologi kelas $X$ adalah 70.

\section{Laporan Praktikum}

- Pembuatan laporan perorang atau perkelompok : laporan dibuat perorangan
- Jarak pengumpulan laporan praktikum setelah dilaksanakannya praktikum : jarak pengumpulannya selama 1 minggu setelah praktikum dilaksanakan.

- Dikumpulkan atau tidak laporan praktikum setelah 1 minggu praktikum : selalu dikumpukan apabila sudah 1 minggu setelah praktikum berlangsung.

- Laporan praktikum dikoreksi atau tidak sebelum dikembalikan kepada siswa : Laporan praktikum terlebih dahulu di koreksi dan diberikan nilai sebelum dikembalikan kepada masing-masing siswa.

- Laporan praktikum selalu dikembalikan kepada siswa atau tidak setelah dikoreksi dan dinilai : Laporan praktikum selalu dikembalikan kepada siswa setelah dikoreksi dan dinilai.

\section{Persiapan Praktikum}

- Pengelompokan siswa dilakukan oleh guru atau siswa sendiri yang memilih kelompok : Guru yang berperan membagi siswa dalam 8 kelompok.

- Diberikan penjelasan terlebih dahulu atau tidak sebelum melaksanakan praktikum : Pada saat ingin melaksanakan praktikum, terlebih dahulu diberikan penjelasan mengenai materi yang akan dipraktikumkan.

Faktor-Faktor yang Menghambat Pelaksanaan Praktikum Biologi di Kelas X SMA N 16 Medan

Berdasarkan hasil data dari angket kepada siswa dan wawancara kepada guru biologi kelas $X$, beberapa faktor yang dapat menghambat pelaksanaan praktikum di SMA N 16 Medan yaitu peralatan yang diperlukan untuk melaksanakan praktikum tidak semuanya tersedia di laboratorium, waktu yang tersedia untuk melaksanakan praktikum biologi tidak mencukupi, jarang melaksanakan praktikum pemanfaatan alam, tidak adanya waktu tambahan dalam melakukan praktikum, jarang melaksanakan ujian tes sebelum melaksanakan praktikum biologi sehingga siswa tidak menghafal terlebih dahulu mengenai prosedur kerja dan materi yang akan dipraktikumkan dan lembar kerja siswa sering tidak digunakan pada saat praktikum.

Kendala-kendala yang dialami Guru dalam Pelaksanaan Praktikum Biologi di kelas X SMA N 16 Medan.

Berdasarkan hasil wawancara dengan guru biologi, terdapat beberapa kendala-kendala yang 
dialami oleh guru dalam pelaksanaan praktikum biologi di kelas X SMA N 16 Medan yaitu : ketersediaan waktu untuk kegiatan praktikum, sumber rancangan praktikum seperti buku penuntun praktikum yang kurang tersedia, tidak adanya laboran untuk membantu guru mempersiapkan alat dan bahan di laboratorium dan suasana praktikum yang kurang kondusif karena banyak siswa yang ribut.

\section{PEMBAHASAN}

Berdasarkan data hasil penelitian yang diperoleh dari angket yang diberikan kepada siswa mengenaii analisis pelaksanaan praktikum pada mata pelajaran biologi belum menunjukkan bahwa kegiatan praktikum di kelas X SMA N 16 Medan berjalan dengan optimal, hal ini dapat dilihat dari setiap deskriptor yang terdapat pada angket.

\section{Keadaan Laboratorium}

Peralatan di laboratorium sangat menunjang kelancaran pelaksanaan praktikum. Peralatan di laboratorium berdasarkan analisis angket masuk ke dalam kriteria cukup baik dengan persentase 57,7\%. Berdasarkan hasil wawancara dengan guru biologi bahwa peralatan di laboratorium SMA N 16 Medan cukup lengkap, namun ada beberapa alat yang tidak tersedia di laboratorium seperti neraca, potometer, termometer suhu tanah, kuadrat, dan stop watch. Menurut Yennita (2014), disamping usaha oleh pihak sekolah dan instansi terkait dalam mencukupi peralatan praktikum, guru juga dapat menemukan solusi dengan cara membuat media pembelajaran alternatif menggunakan barang-barang sederhana.

Tata tertib di laboratorium sangat penting untuk dilaksanakan supaya tidak terjadi kecelakaan ataupun hal-hal yang tidak diinginkan selama melaksanakan praktikum. Menurut Yaman (2016), Adapun tata tertib yang harus dilakukan siswa adalah : siswa tidak dibenarkan masuk kedalam ruangun laboratorium tanpa izin guru pembimbing, siswa masuk laboratorium menggunakan sepatu yang bersih tidak dibenarkan membawa makanan ke dalam ruang laboratorium, siswa diharuskan menempati tempat yang ditentukan sesuai dengan kelompok kerja, harus menggunakan alat dan bahan sesuai petunjuk praktikum, siswa wajib meminjam alat sesuai dengan kartu peminjaman, dan jika ada alat yang rusak siswa harus melaporkan kepada guru pembimbing, jika terjadi kecelakaan dalam praktikum siswa harus melapor kepada guru pembimbing, setelah melakukan praktikum siswa harus mengembalikan alat/bahan ke tempat semula dalam keadaan bersih dan rapi, laboratorium harus dalam keadaan bersih dan rapi setelah selesai kegiatan praktikum, kerusakan atau kehilangan alat akibat kelalaian siswa wajib dilaporkan kepada guru pembimbing, siswa yang tidak mematuhi tata tertib diberi sanksi oleh guru pembimbing. Tata tertib di laboratorium berdasarkan analisis angket termasuk dalam kriteria baik dengan persentase $69,68 \%$.

Kebersihan ruangan praktikum sangat mendukung terlaksananya praktikum, jika ruangan kotor maka siswa maupun guru tidak akan merasa nyaman untuk melaksanakan praktikum. Berdasarkan hasil wawancara dengan guru biologi bahwa sebelum memulai dan setelah selesai melaksanakan praktikum, ruangan praktikum selalu dibersihkan. Kebersihan ruangan praktikum berdasarkan analisis angket termasuk dalam kriteria baik dengan persentase $77,18 \%$.

Menggunakan alat keselamatan saat praktikum seperti masker, sarung tangan, dan baju praktikum merupakan alat yang sangat penting digunakan saat ingin melaksanakan praktikum supaya siswa ataupun praktikan terhindar dari bahaya. Siswa diwajibkan menggunakan masker agar bahan-bahan yang berbahaya tidak terhirup, menggunakan sarung tangan supaya bahan-bahan berbahaya tidak mengenai kulit, menggunakan baju praktikum supaya bahan-bahan praktikum tidak mengenai pakaian ataupun seragam sekolah. Menggunakan alat keselamatan saat praktikum berdasarkan analisis angket termasuk dalam kriteria baik dengan persentase $77,18 \%$.

\section{Waktu Pelaksanaan Praktikum}

Waktu untuk melaksanakan praktikum terkadang tidak mencukupi. Berdasarkan hasil wawancara dengan guru biologi bahwa waktu pelaksanaan praktikum dilakukan sejalan dengan jam pelajaran tetapi tidak ada waktu khusus. Pelaksanaan praktikum hanya dilakukan saat mata pelajaran biologi, guru tidak membuat jadwal yang khusus untuk melaksanakan praktikum. Menurut Adisendjaja (2008), pada umumnya kendala dalam pelaksanaan praktikum adalah waktu yang sangat menyita, sekolah-sekolah biasanya sudah memiliki jadwal yang sudah pasti untuk setiap mata pelajaran dan tidak mempertimbangkan waktu praktikum. Alokasi waktu berdasarkan analisis angket termasuk dalam kriteria cukup baik dengan persentase $58,75 \%$.

Melakukan praktikum pemanfaatan alam (praktikum di luar ruangan) sangat membantu siswa untuk lebih memahami materi yang akan 
dipraktikumkan misalnya untuk melihat morfologi tumbuhan, siswa bisa langsung melihat dan meraba bagaimana tepi daun, benang sari pada bunga, tangkai daun dan sebagainya. Berdasarkan hasil wawancara dengan guru biologi, guru pernah melakukan praktikum pemanfaatan alam namun hanya sekali pada saat praktikum keanekaragaman hayati. Praktikum dilakukan dipekarangan sekolah, namun dengan membawa tambahan bahan yang dibawa oleh siswa. Melakukan praktikum pemanfaatan alam berdasarkan analisis angket termasuk dalam kriteria kurang baik yaiu dengan persentase $26,87 \%$.

\section{Buku Penuntun Praktikum}

Kesesuaian pelaksanaan praktikum biologi dengan penuntun praktikum. Saat melaksanakan praktikum perlu adanya kesesuaian dengan penuntun praktikum ataupun LKS yang digunakan agar siswa dapat mempelajari terlebih dahulu mengenai materi yang akan dipraktikumkan. Menurut Hamidah (2014), Untuk menunjang pelaksanaan praktikum,diperlukan adanya buku panduan praktikum. Kesesuaian pelaksanaan praktikum biologi dengan penuntun praktikum berdasarkan analisis angket termasuk dalam kriteria baik dengan persentase $69,37 \%$.

\section{Ketersediaan Waktu}

Dalam kegiatan praktikum, guru harus memperhatikan kesesuaian praktikum dengan jadwal biologi. Di SMA N 16 Medan, guru cukup memperhatikan kesesuaian praktikum dengan jadwal biologi. Menurut penelitian Yennita (2014), Praktikum dilaboratorium membutuhkan ketepatan waktu, karena dilakukan pada saat jam pelajaran yang memiliki keterbatasan waktu tertentu. Oleh sebab itu, guru harus benar-benar mempersiapkannya sebelum jam pelajaran tersebut berlangsung. Kesesuaian praktikum dengan jadwal biologi berdasarkan analisis angket termasuk dalam kriteria baik dengan persentase $68,12 \%$.

Penggunaan waktu praktikum yang cukup dalam pelaksanaannya. Dalam kegiatan praktikum, guru harus memiliki manajemen waktu yang baik supaya kegiatan praktikum bisa diselesaikan tepat waktu. Berdasarkan hasil wawancara dengan guru biologi, waktu yang dilakukan cukup dan selalu selesai sesuai dengan jadwal yang telah ditentukan. Saat melaksanakan praktikum, waktu yang digunakan selalu cukup sehingga tidak perlu diadakan waktu tambahan setelah pulang sekolah. Penggunaan waktu praktikum berdasarkan analisis angket termasuk dalam kriteria baik dengan persentase $62,18 \%$.
Ada tidaknya waktu tambahan dalam melakukan praktikum. Guru dapat memberikan waktu tambahan jika waktu untuk melaksanakan praktikum tidak mencukupi misalnya pada saat pulang sekolah. Tidak adanya waktu tambahan dalam melakukan praktikum berdasarkan analisis angket termasuk dalam kriteria cukup baik dengan persentase $58,43 \%$.

\section{Materi}

Prosedur kerja harus sesuai dengan materi biologi yang akan dipraktikumkan, agar siswa tidak salah menafsirkan apa yang akan dipraktikumkan. Berdasarkan hasil wawancara dengan guru biologi, prosedur kerja sesuai dengan materi pelajaran biologi yang akan dipraktikumkan. Kesesuaian prosedur kerja dengan materi biologi berdasarkan analisis angket termasuk dalam kriteria baik dengan persentase $76,25 \%$.

Pendalaman materi biologi melalui kegiatan praktikum. Tentu pada saat melaksanakan praktikum, siswa akan lebih memahami apa yang telah mereka pelajari di teori karena pada kegiatan praktikum, siswa diajak untuk mempraktekkan, meramalkan dan mengamati sendiri apa yang mereka praktikumkan. Berdasarkan wawancara dengan guru biologi, sebagian siswa aktif dalam melakukan praktikum dan sebagian lagi kurang aktif. Siswa yang tidak fokus saat praktikum, mereka lebih memilih melakukan aktifitas yang lain seperti bermain HP dan bercanda dengan teman-temannya daripada melakukan praktikum. Pendalaman materi biologi melalui kegiatan praktikum berdasarkan analisis angket termasuk dalam kriteria baik dengan persentase $66,87 \%$.

\section{Pelaksanaan Praktikum}

Hasil pengamatan praktikum biologi sesuai dengan prosedur praktikum. Hasil pengamatan praktikum memang seharusnya sesuai dengan prosedur praktikum. Namun terkadang siswa dapat melakukan kesalahan saat melaksanakan praktikum, ada beberapa siswa yang tidak memperhatikan dengan jelas prosedur praktikum hingga mengakibatkan hasil yang didapat menjadi berbeda. Hasil pengamatan praktikum biologi berdasarkan analisis angket sesuai dengan prosedur praktikum termasuk dalam kategori baik dengan persentase $77,18 \%$.

Pemahaman siswa mengenai prosedur kerja pada kegiatan praktikum. Pada dasarnya guru telah memberikan penjelasan terlebih dahulu mengenai prosedur kerja sebelum melaksanakan praktikum, sebagian besar siswa memahami dengan baik namun ada saja siswa yang tidak memperhatikan. 
Pemahaman siswa mengenai prosedur kerja pada kegiatan praktikum berdasarkan analisis angket termasuk dalam kriteria baik dengan persentase $71,87 \%$.

Guru mengadakan tes tertulis sebelum praktikum. Mengadakan tes sebelum ataupun sesudah praktikum memang sangat penting. Selain untuk mengetahui kemampuan siswa, siswa juga bisa mempersiapkan diri di rumah dengan membaca materi yang terkait dengan kegiatan praktikum. Guru mengadakan tes tertulis sebelum praktikum berdasarkan analisis angket termasuk dalam kriteria baik dengan persentase $61,87 \%$.

Pada saat praktikum, siswa diberikan kesempatan yang sama untuk mengamati ataupun mempraktekkan apa yang dipraktikumkan, namun terkadang waktu yang diperlukan untuk siswa mengamati satu per satu tidak mencukupi. Kesempatan untuk mengamati praktikum berdasarkan analisis angket termasuk dalam kriteria baik dengan persentase $75 \%$.

Siswa memakai jas laboratorium pada saat melakukan praktikum. Jas laboratorium merupakan alat keselamatan yang sangat penting saat melakukan praktikum, selain melindungi kulit dari bahan-bahan yang berbahaya, jas laboratorium juga mencegah supaya pakaian kita tetap bersih dari bahan-bahan atau pun cairan yang digunakan saat praktikum. Siswa memakai jas laboratorium pada saat melakukan praktikum biologi berdasarkan analisis angket termasuk dalam kriteria baik dengan persentase $72,5 \%$.

\section{Lembar Kerja Siswa}

Lembar kerja siswa (LKS) memiliki peranan yang sangat penting untuk membantu siswa memahami materi yang akan dipraktikumkan. Namun terkadang LKS ini tidak diberikan guru kepada siswa sehingga siswa memiliki kendala dalam melakukan praktikum. Diberikan atau tidak lembar kerja siswa pada saat melakukan praktikum berdasarkan analisis angket termasuk dalam kriteria baik dengan persentase $64,1 \%$.

Lembar kerja siswa dipergunakan atau tidak pada saat melakukan praktikum. Lembar kerja siswa dipergunakan saat praktikum namun pernah 2 kali tidak digunakan. Lembar kerja siswa tersebut dipergunakan atau tidak pada saat melakukan praktikum berdasarkan analisis angket termasuk dalam kriteria cukup baik dengan persentase 54,68\%.

\section{Pembuatan Laporan}

Memahami cara pembuatan laporan setiap melakukan praktikum. Guru telah menjelaskan terlebih dahulu bagaimana cara membuat laporan praktikum. Sebagian besar siswa telah memahami cara pembuatan laporan. Memahami cara pembuatan laporan setiap melakukan praktikum berdasarkan analisis angket termasuk dalam kriteria baik dengan persentase $73,43 \%$.

Kendala dalam pembuatan laporan. Meskipun guru telah menjelaskan cara pembuatan laporan namun siswa masih ada yang tidak paham sehingga terkadang salah saat mengisi laporan praktikum. Kendala dalam pembuatan laporan berdasarkan analisis angket termasuk dalam kriteria baik dengan persentase $66,25 \%$.

Siswa selalu mencatat dan menggambarkan hasil pengamatan praktikum. Guru telah memberikan arahan kepada siswa untuk mencatat dan menggambarkan hasil pengamatan praktikum sebagai laporan sementara yang akan diperiksa oleh guru setelah selesai melaksanakan praktikum. Siswa selalu mencatat dan menggambarkan hasil pengamatan praktikum berdasarkan analisis angket termasuk dalam kriteri baik dengan persentase $76,25 \%$.

Guru mengumpulkan laporan praktikum. Guru selalu mengumpulkan laporan praktikum setelah waktu yang diberikan untuk siswa mengerjakan telah habis yaitu 1 minggu. Berdasarkan hasil wawancara dengan guru biologi, laporan praktikum seslalu dikumpulkan apabila sudah 1 minggu setelah praktikum berlangsung. Guru mengumpulkan laporan praktikum berdasarkan analisis angket termasuk dalam kriteria baik dengan persentase $75 \%$.

Guru mengoreksi laporan praktikum biologi. Sebelum laporan dikembalikan kepada siswa, guru terlebih dahulu mengoreksi laporan praktikum masing-masing siswa dan memberikan penilaian. Berdasarkan hasil wawancara dengan guru biologi, laporan praktikum terlebih dahulu mengoreksi dan menilai laporan siswa sebelum dikembalikan. Sesuai dengan analisis angket siswa yang termasuk dalam kriteria baik dengan persentase $77,18 \%$.

Guru mengembalikan laporan praktikum yang telah dikoreksi. Setelah selesai dikoreksi oleh guru, guru selalu mengembalikan laporan kepada masingmasing siswa, agar siswa dapat melihat kesalahan yang dibuat dan dapat memperbaikinya pada pertemuan selanjutnya. Sesuai dengan hasil wawancara dengan guru biologi, guru selalu mengembalikan laporan praktikum setelah dikoreksi. Berdasarkan analisis angket, guru mengembalikan 
laporan praktikum yang telah dikoreksi termasuk dalam kriteria baik dengan persentase $73,43 \%$.

Siswa mampu menarik kesimpulan yang relevan. Sebagian siswa mampu menarik kesimpulan dengan baik sesuai dengan tujuan praktikum namun ada beberapa siswa yang membuat kesimpulan tidak berdasarkan tujuan praktikum. Siswa mampu menarik kesimpulan yang relevan terhadap hasil percobaan berdasarkan analisis angket termasuk dalam kriteria baik dengan persentase $69,37 \%$.

\section{Persiapan Praktikum}

Pengelompokan siswa dibagi langsung oleh guru menjadi 8 kelompok. Sesuai dengan wawancara dengan guru biologi, guru sendiri yang membagi kelompok. Jika siswa yang membagi sendiri kelompoknya, maka siswa akan memilih teman-teman terdekatnya sehingga siswa tidak berbaur dengan teman-teman yang lain. Pengelompokan siswa pada saat praktikum berdasarkan analisis angket termasuk dalam kriteria baik dengan persentase $67,5 \%$.

Peranan guru dalam memberikan penjelasan terlebih dahulu. Sebelum melaksanakan praktikum, guru menjelaskan terlebih dulu materi apa yang akan dipraktikumkan. Misalnya praktikum mengenai virus, guru terlebih dahulu menjelaskan apa yang akan diamati dari virus tersebut. Berdasarkan analisis angket, peranan guru dalam memberikan penjelasan terlebih dahulu tentang kegiatan yang akan dilakukan termasuk dalam kriteria baik dengan persentase 79,37\%.

Guru menyampaikan tujuan praktikum sebelum melaksanakan praktikum. Sebelum melaksanakan praktikum, guru terlebih dahulu menjelaskan mengenai tujuan praktikum. Misalnya praktikum tentang jamur, tujuannya untuk mengetahui ciri-ciri jamur. Berdasarkan analisis angket, guru menyampaikan tujuan praktikum sebelum melaksanakan praktikum biologi termasuk dalam kriteria sangat baik dengan persentase $85,62 \%$.

\section{Faktor-faktor yang Menghambat Pelaksanaan Praktikum Biologi di Kelas X SMA N 16 Medan}

Peralatan yang diperlukan untuk melaksanakan praktikum tidak semuanya tersedia di laboratorium. Menurut Rezeqi (2014), Laboratorium yang baik harus dilengkapi dengan berbagai fasilitas untuk memudahkan pemakaian laboratorium dalam melakukan aktivitasnya. Fasilitas tersebut ada yang berupa fasilitas umum dan fasilitas khusus. Fasilitas umum merupakan fasilitas yang dapat digunakan oleh semua pemakai laboratorium contohnya penerangan, ventilasi, air, bak cuci (sinks), aliran listrik dan gas.
Fasilitas khusus berupa peralatan dan belajar, contohnya meja siswa, meja guru, kursi, papan tulis, lemari alat, lemari bahan, ruang timbang, lemari asam, perlengkapan $\mathrm{P} 3 \mathrm{~K}$, pemadam kebakaran dan lain-lain.

Waktu yang tersedia untuk melaksanakan praktikum biologi tidak mencukupi. Sama halnya dengan salah satu kendala yang dialami oleh guru. Waktu yang tersedia tidak mencukupi untuk menyelesaikan sebuah eksperimen, belum lagi guru harus mempersiapkan praktikum dan mengemas kembali berbagai peralatan setelah praktikum selesai dilaksanakan. Oleh sebab itu, guru harus benar-benar mempersiapkannya sebelum jam pelajaran tersebut berlangsung.

Jarang melaksanakan praktikum pemanfaatan alam. Hal ini dikarenakan masih banyaknya sekolah yang belum memiliki kebun Biologi dan juga karena faktor guru yang masih enggan mengontrol siswa apabila dilakukan praktikum di luar ruangan dan juga keterbatasan waktu.

Tidak adanya waktu tambahan dalam melakukan praktikum. Sesuai dengan wawancara dengan guru biologi, tidak ada penambahan waktu di luar jam pelajaran biologi misalnya sore hari setelah jam pelajaran selesai. Begitu juga apabila terjadi kegagalan pada pelaksanaan praktikum maka tidak ada pengulangan di luar jam pelajaran biologi.

Jarang melaksanakan ujian tes sebelum melaksanakan praktikum biologi sehingga siswa tidak menghafal terlebih dahulu mengenai prosedur kerja dan materi yang akan dipraktikumkan.

\section{Kendala-kendala yang dialami Guru dalam Pelaksanaan Praktikum Biologi di kelas X SMA N 16 Medan.}

Ketersediaan waktu untuk kegiatan praktikum. Hal ini seharusnya dapat diatasi jika guru benar-benar merencanakan alokasi waktu untuk tahap-tahap pembelajaran dengan matang. Menurut Sardiman (2012), guru dapat mengatur alokasi waktu masing - masing tahapan pembelajaran dengan memperkirakan seberapa besar porsi waktu yang pantas diberikan untuk masing-masing tahap.

Sumber rancangan praktikum seperti buku penuntun praktikum yang kurang tersedia. Sumber rancangan praktikum yang dimaksud adalah buku penuntun praktikum. Ketersediaan buku penuntun praktikum sangat penting karena dapat menjadi pedoman pelaksanaan praktikum bagi siswa. Solusi yang dapat ditempuh oleh guru yaitu dengan melihat contoh dari penuntun praktikum melalui buku-buku 
ataupun yang ada di website dan kemudian dimodifikasi sesuai dengan peralatan yang ada di sekolah.

Tidak adanya laboran untuk membantu guru mempersiapkan alat dan bahan di laboratorium. Praktikum sangat membutuhkan dukungan dari berbagai pihak, diantaranya adalah kepala sekolah dan tenaga laboran yang bertugas membantu guru dalam pelaksanaan praktikum di laboratorium. Tidak adanya laboran menyebabkan praktikum relatif sulit untuk dilaksanakan.

Suasana praktikum yang kurang kondusif karena banyak siswa yang ribut. Menurut Atnur (2014), beberapa orang siswa mengakui hal ini sangat mengganggu konsentrasi dalam melaksanakan kegiatan praktikum. Seharusnya siswa dapat lebih tertib dan memiliki minat dalam melaksanakan praktikum sehingga kegiatan praktikum yang dilaksanakan dapat membantu siswa dalam memahami materi pembelajaran.

\section{KESIMPULAN}

Pelaksanaan Praktikum Biologi di kelas X SMA N 16 Medan belum terlaksana dengan baik. Berdasarkan data angket dan hasil wawancara dengan guru bidang studi biologi, praktikum dilakukan \pm 3 kali dalam 1 semester. Faktor-faktor yang menghambat pelaksanaan praktikum biologi yaitu, peralatan yang diperlukann untuk melaksanakan praktikum tidak tersedia semuanya di laboratorium, waktu yang tersedia untuk melakukan praktikum tidak mencukupi, jarang melaksanakan praktikum pemanfaatan alam, tidak adanya waktu tambahan dalam melakukan praktikum, guru jarang melakukan tes sebelum ataupun sesudah praktikum, dan lembar kerja siswa sering tidak dipergunakan pada saat praktikum. Kendala-kendala yang dihadapi oleh guru biologi dalam pelaksanaan praktikum biologi di kelas X SMA N 16 Medan adalah siswa belum memiliki buku penuntun praktikum sendiri, ketersediaan waktu untuk kegiatan praktikum, sumber rancangan praktikum seperti buku penuntun praktikum tidak tersedia, tidak adanya laboran untuk membantu guru mempersiapkan alat dan bahan di laboratorium serta suasana praktikum yang kurang kondusif.

\section{UCAPAN TERIMA KASIH}

Terima kasih terkhusus kepada dosen pembimbing, Dra. Masdiana Sinambela, M.Si., yang telah banyak memberikan banyak masukan dan saran hingga terselesaikannya penelitian ini. Dan kepada Ibu Hj. Fauziah Hasibuan, S.Pd, M.Si., selaku Kepala
Sekolah SMA Negeri 16 Medan, Ibu Septie S.Pd., selaku guru biologi SMA Negeri 16 Medan yang bimbingannya selama penelitian berlangsung dan siswa-siswi kelas X MIA yang telah banyak membantu selama penelitian berlangsung.

\section{DAFTAR PUSTAKA}

Adisendjaja., (2008). Kegiatan Praktikum dalam Pendidikan Sains, Bio-UPI, Bandung.

Arikunto, S., (2013), Manajemen Penelitian, Rineka Cipta, Jakarta.

Atnur, W., dan Lufri., dan Sumarmin, R., (2014), Analisis Pelaksanaan Praktikum IPA Biologi Kelas VIII Semester 1 dii SMP Negeri SeKecamatan Lubuk Begalung Tahun Pelajaran 2014/2015

Dalora, P., (2014), Analisis Pelaksanaan Praktikum Biologi di SMA Negeri Se-Kota Jambi, Artikel, Universitas Negeri Jambi.

Hamidah, A., Sari, N., dan Budianingsih, R., (2014), Persepsi Siswa Tentang Kegiatan Praktikum Biologi di Laboratorium SMA Negeri Se-Kota Jambi, Jurnal Sainmatika. Vol 8 No 12014.

Muliadong., Nurul, A., dan Ria, K., (2015), Analisis Pelaksanaan Praktikum Biologi SMA Negeri 1 dan SMA Negeri 2 Kecamatan Tambusai. Artikel Ilmiah Mahasiswa, Fakultas Keguruan dan IImu Pendidikan, Universitas Pasir Pengaraian.

Oktavia, I., Subchan, W., dan Hariani, S., (2012), Hubungan Tingkat Intensitas dan Kualitas Kegiatan Praktikum di Laboratorium Biologi dengan Hasil Belajar Siswa SMA Negeri di Kabupaten Situbondo. Artikel Ilmiah Mahasiswa, Jurusan Pendidikan MIPA, Fakultas Keguruan dan Ilmu Pendidikan, Universitas Jember.

Rezeqi, S., (2011), Analisis Pelaksanaan Praktikum Biologi dan Permasalahannya di SMA Negeri Se-Kabupaten Karo, Tesis, Program Pascasarjana UNIMED, Medan.

Sardiman, A., (2012), Interaksi dan Motivasi Belajar Mengajar, Raja Grafindo, Jakarta.

Sudijono., (2010), Pengantar Statistik Pendidikan, Raja Grafindo, Jakarta.

Wahyuni, D., (2013), Pengembangan Petunjuk Praktikum Kimia Kelas XI Pada Topik Kapasitas Larutan Penyangga Universitas Pendidikan Indonesia, Artikel, Universitas Pendidikan Indonesia.

Yaman, E., (2016), Pengoptimalan Peran Kepala Labor dalam Menunjang Pembelajaran IPA di SMPN 7 
JURNAL PELITA PENDIDIKAN VOL. 5 NO. 2

pISSN : $2338-3003$

Siburian, F., Sinambela, M., Septie

Halaman : $021-031$

Kubung, Jurnal Penelitian Guru Indonesia, Vol 1, No 1, Kubung.

Yennita., Mugi, S., dan Zulirfan., (2014), Hambatan Pelaksanaan Praktikum IPA Fisika yang Dihadapi Guru SMP Negeri di Kota Pekanbaru, Artikel, Jurusan PMIPA FKIP, Universitas Riau. 